\title{
Analysis of Marketing Mix Characteristics of Marketing Factor 7P (Product, Price, Place, Promotion, People, Process, Physical Building) to Patient Satisfaction of Inpatient Patient Hospital Muhammadiyah Ahmad Dahlan Kediri City
}

\author{
Tety Yuliantine ${ }^{1}$, Indasah ${ }^{2}$, \\ Sandu Siyoto ${ }^{2}$ \\ ${ }^{1}$ Magister of Health Study \\ Program of STIKes Surya Mitra \\ Husada Kediri \\ ${ }^{2}$ Lecturer of STIKes Surya Mitra \\ Husada Kediri \\ tety.yuliantine@gmail.com
}

\begin{abstract}
Hospital marketing mix is a group of variables tht can be controlled and used the hospital to influence the reaction of the users of services. The aim of the study is to analize the effect of marketing mix 7P(product, price, place, promotion, process, people, physical building) on patient satisfaction in inpatient hospital of Muhammadiyah Ahmad Dahlan Kediri City. The type of this research is quantitative research with analytic observational research design with cross sectional approach. The study was conducted on October until December 31, 2017 at Muhammadiyah Ahmad Dahlan Hospital Kediri City with 600 inpatient patients as the population. The sample size is 240 respondents. Data were collected using questionnaires. Data were multiple linear regression test with $\alpha=0,05$. The results showed that the most of the respondents are female $(53,3 \%)$, between ages $20-35$ years $(52,1 \%)$ educated high school eqivalent $(39,6 \%)$, working private $(34,6 \%)$, pay with BPJS $(76,25 \%)$, stay in class III $(56,7 \%)$. The analysis indicated that F-test $=$ 90,484 sig. $0,000, t$ test $=6,579$ sig $0,000, R 2=73,2$. there is a influence of product $(\mathrm{p}=0,000)$, price $(\mathrm{p}=0,000)$, place $(\mathrm{p}=0,000)$, promotion $(\mathrm{p}=0,000)$, process $(\mathrm{p}=0,000)$, people $(p=0,000)$, physical building $(p=0,000)$ have effect of patient satisfaction. The most influential variable is physical building $(\beta=0,442)$. Marketing mix has asignificant effect on patient satisfaction of inpatient hospital of Muhammadiyah. Suggested to the hospital to further improve the marketing mix strategies of the hospital so that patient satisfaction can be achieved.
\end{abstract}

Keywords : Marketing mix, Product, Price, Place, Promootion, Process, People, Physical Building, Patient Satisfaction.

Published : May 11, 2018

Copyright (C) 2018 STIKes Surya Mitra Husada

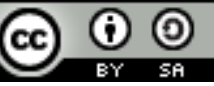

This is an open-acces article distributed under the terms of the Creative Commons Attribution-ShareAlike 4.0 International License. 


\section{INTRODUCTION}

The hospital is one of the health service facilities organized by the government and private. According to the Law of the Republic of Indonesia No.44 of 2009 concerning Hospitals has the duty to provide personal health services in plenary(including promotive, preventive, curative and rehabilitative) by providing inpatient, outpatient and emergency services). In line with the mandate of article 28H, paragraph (1) of the amendment of the 1945 Constitution of the Republic of Indonesia has been affirmed that every person has the right to health care and Article 34 Paragraph (3) states that the state is responsible for the provision of health service facilities, decent public service facilities (Alfianti et al., 2010).

The hospital is one of the health service facilities organized by the government and private. According to the Law of the Republic of Indonesia No.44 of 2009 concerning Hospitals has the duty to provide personal health services in plenary (including promotive, preventive, curative and rehabilitative) by providing inpatient, outpatient and emergency services). In line with the mandate of article 28H, paragraph (1) of the amendment of the 1945 Constitution of the Republic of Indonesia has been affirmed that every person has the right to health care and Article 34 Paragraph (3) states that the state is responsible for the provision of health service facilities, decent public service facilities (Alfianti et al., 2010).

The new paradigm of health services requires hospitals to provide quality services according to the needs and wants of patients. The development of the hospital is currently running rapidly, thus creating an increasingly fierce competition. This requires a hospital to be more sensitive, critical, and reactive to existing changes. The function of the hospital which was originally only as a place for treatment, has now evolved towards the unity of service efforts for the whole society which includes the promotive, preventive, curative and rehabilitative aspects (Rengkuan et al, 2014).

People with various characteristics are very selective in choosing hospital health services. People will choose the hospitals they see as satisfying them. This causes the competition between hospitals is very tight in attracting consumers to access health services in the hospital. One way that can be done by hospitals to attract consumers to their products is to conduct marketing activities. Understanding that consumers are the foundation of marketing, the organization must be able to understand how consumers individually see, think, feel and act on service and products, price fixing, distribution, and promotion in order to survive and thrive. (Hurriyati, Rati, 2010).

Marketing is an activity of analysis, planning, product / service offerings and program controls carefully formulated to generate voluntary exchange of values with target markets intended to achieve organizational goals. Hospital marketing can be implemented to make hospital utilities higher by learning and understanding consumer behavior. Fulfillment efforts and customer expectations can create an increase in the number of service utilization. One of the most important things to know in marketing is the marketing mix. The marketing mix is the hospital's principal business that is closely related to the patient's behavior to make use of the service. The marketing mix is expected to improve the patient's positive perception. Marketing mix is a set of marketing tools that a company uses to achieve its marketing objectives in its target market. The marketing mix consists of $7 \mathrm{P}$ covering product, price $/$ price, distribution / place, promotion / promotion, people, process, physical building (Nurlia, 2012).

Customer satisfaction is closely related to the expected service and the reality of the service that has been provided. After receiving the health service, the patient will compare the services experienced with the expected services. If the perceived services are not in accordance with the services expected, then the patient is not satisfied but if the perceived service meets or even exceeds the patient's expectations then the patient will be satisfied. (Sudarto, T., 2011). The purpose of this study is to analyze the characteristics of product, price, place, promise, peple, process, physical building through the services of doctors, nursing services, nutrition services, pharmacy services, laboratory services in inpatient rooms Muhammadiyah Hospital Ahmad Dahlan Kota Kediri. 


\section{METHOD}

The type of this research is quantitative research with analytic observational research design with cross sectional approach. The study was conducted on 30th October to 31st December 2017 at Muhammadiyah Hospital Kediri with 600 inpatients class I, II, III. The sample size is 240 respondents. Data were collected using questionnaires. Data were analyzed using multiple linear regression test with $\alpha=0,05$.

\section{RESULTS}

Distribution characteristics of respondents

Tabel 1. Characteristics of respondents in this study include age, education, employment, mode of payment, and treatment classes, gender.

\begin{tabular}{|c|c|c|c|}
\hline No & Characteristics & $\mathbf{\Sigma N}$ & $\Sigma \%$ \\
\hline \multirow[t]{4}{*}{1} & Ages(years) & & \\
\hline & $<20$ & 13 & 5,4 \\
\hline & $20-35$ & 125 & 52,1 \\
\hline & $>35$ & 102 & 42,5 \\
\hline \multirow[t]{6}{*}{2} & Education & & \\
\hline & SD & 36 & 15 \\
\hline & SMP & 40 & 16,3 \\
\hline & SMA & 95 & 39,6 \\
\hline & College & 50 & 20,8 \\
\hline & Etc & 20 & 5,3 \\
\hline \multirow[t]{7}{*}{3} & Employment & & \\
\hline & Civil servant & 13 & 5,4 \\
\hline & Self employed & 79 & 32,9 \\
\hline & Labour & 19 & 7,9 \\
\hline & Private & 83 & 34,6 \\
\hline & Farmer & 21 & 8,8 \\
\hline & Etc & 25 & 10,4 \\
\hline \multirow[t]{5}{*}{4} & mode of payment & & \\
\hline & Out of pocket & 49 & 20,42 \\
\hline & BPJS & 183 & 76,25 \\
\hline & Jamkesda & 4 & 1,67 \\
\hline & Other insurance & 4 & 1,67 \\
\hline \multirow[t]{4}{*}{5} & Treatment classes & & \\
\hline & Grade I & 24 & 10 \\
\hline & Grade II & 80 & 33,3 \\
\hline & Grade III & 136 & 56,7 \\
\hline \multirow[t]{4}{*}{6} & Gender & & \\
\hline & Male & 112 & 46,7 \\
\hline & Female & 128 & 53,3 \\
\hline & Total & 240 & 100 \\
\hline
\end{tabular}

Based on the table 1 above, it is known that from the total of 240 respondents aged between 20-35 years, 125 respondents (52.1\%), high school education, 95 respondents (39.6\%), private sector employed 83 respondents $(34,6 \%)$, paying the cost of care through insurance BPJS that is as much as 183 Respondents $(76,25 \%)$, most class of care is class III that is 136 respondent $(56,7 \%)$, female gender 128 responden $(53.3 \%)$ 


\section{RESULTS OF STATISTICAL TESTS}

From the result of cross product tabulation to patient satisfaction from 240 respondents, most of respondents stated good product and patient satisfaction either 233 respondents $(97,1 \%)$, from result of Spearman rho got $p=0,000$. Price of patient satisfaction most of respondents stated that affordable tariff and patient satisfaction either 234 responders $(97,5 \%)$, from result of Spearman rho got $p=0,000$. Place to patient satisfaction, most of respondents stated good place and patient satisfaction either 233 respondents $(97,1 \%)$, from result of Spearman rho got $p=0,000$. which means that there is a relationship between place and patient satisfaction. Promotion of patient satisfaction most of the respondents stated good promotion and patient satisfaction both 232 respondents $(96,7 \%)$, from result of spearman rho got $p=0,000$. Good people and patient satisfaction both 230 respondents $(95.8 \%)$, spearman rho $p=0,000$. The process of patient satisfaction most of the respondents stated good process and patient satisfaction either 234 respondents $(97.5 \%)$, from spearman rho results obtained $p$ $=0.000$. Physical Building on patient satisfaction most respondents stated good physical building and good patient satisfaction that is 235 respondents $(97,9 \%)$, from result of spearman rho got $\mathrm{p}=0,000$.

The simultaneous test results $\mathrm{F}=90.484$ sig, 000 which means $<0.05$, so $\mathrm{H} 1$ is accepted. This shows the effect of simultaneous product, price, place, promotion, people, process, physical building on Patient Satisfaction of Muhammadiyah Hospital Kediri.

$\mathrm{R}$ Square value of 0.732 or $0.732 \times 100 \%=73.2 \%$, thus indicating that Patient Satisfaction with (X1), price (X2), place (X3), promotion (X4), people (X5), process (X6)), physical building (X7) is $73,2 \%$ and the rest is $26,8 \%$ explained other variable not studied in this research.

From partial test obtained $\mathrm{p}$-value $=0,00$ which means $<0,05$, so H1 accepted, so every each variable have significant effect to patient satisfaction. The most dominant variable is physical building of 0.442 .

\section{DISCUSSION}

\section{The effect of the product on the satisfaction of the inpatient patient of Muhammadiyah Ahmad Dahlan Hospital Kediri}

This research shows that the product has a significant effect on the satisfaction of the patient while staying in the Muhammadiyah Ahmad Dahlan Hospital Kediri, with the result of $\mathrm{p}$ value of $0.00<\alpha=0.05$, so $\mathrm{H} 0$ is rejected $\mathrm{H} 1$ accepted. The conclusion taken is the product has a significant effect on the satisfaction of inpatients of Muhammadiyah Ahmad Dahlan Hospital Kediri.

Service products according to Kotler (2012) are everything that manufacturers can offer to be noticed, requested, sought, purchased, used or consumed by the market as a fulfillment of the needs that can satisfy the wants and needs. Products include physical objects, services, people, places, organizations and ideas. While the hospital product in question is a service product of all health services which is the whole concept of an object or process that provides a number of values and benefits to the patient.

Nurse service is very important because nurses are most often face-to-face with patients. Friendly nurse service makes the patient feel at home stay in the hospital. This is in accordance with the vision and mission of the hospital is the realization of a trusted hospital and a reference for the community and able to provide services that paripuna, quality and satisfactory and affordable society. Dissatisfaction of products in the front office, this can happen because of the many queues of patients who sometimes oveerload, so that front officers overwhelmed face the patient queue. In addition to the many queues, the queue of patients who mostly use BPJS cards also require pcare applications before service is done. Officer must enter patient data first. This application is connected to the internet, where the internet network allows interference from service providers. In addition, during the hours of 
service delivery of all hospitals in Indonesia in cooperation with BPJS also use this application.

The effect of the price on the satisfaction of the inpatient patient of Muhammadiyah Ahmad Dahlan Hospital Kediri

The results showed that there is a significant effect of price on patient satisfaction obtained $p$ value $=0.00<\alpha=0.05$, so $\mathrm{H} 0$ rejected $\mathrm{H} 1$ accepted. The conclusion taken is the price has a significant effect on the satisfaction of inpatients of Muhammadiyah Hospital Kediri.

According to Kotler's theory (2012) price is one of the marketing mix elements that generate the most easily adjusted income. Yazid (in Nursalam, 2011) says that the factors that affect satisfaction is cost / cost. The same quality but low-cost hospitals have a higher value in patients.

In this study the questionnaire on the price contains about the affordable room rates and facilities, the existence of cost relief in the form of installments from patients who are less able, reasonable tariff doctors. Most of the respondents agree on the tariff of doctors appropriately, meaning that the doctor's tariff can be reached by the community.

The effect of the place on the satisfaction of the inpatient patient of Muhammadiyah Ahmad Dahlan Hospital Kediri

Result of research indicate that there is significant influence place to patient satisfaction obtained $\mathrm{p}$ value $=0,00<\alpha=0,05$, so $\mathrm{H} 0$ rejected $\mathrm{H} 1$ accepted. The conclusion taken is place have a significant effect to the satisfaction of inpatient patient of Muhammadiyah Hospital Kediri.

According to Alfianti et al. (2016) place can be interpreted as a place of service. Location services that can be used in supplying services to customers is important because that is produced by human services directly to other humans. In this place variable which in general the distribution is an effort so that the product offered can be in place and time appropriate to consumer's boredom. In the hospital, this variable can be interpreted as a place of health services provided, along with the feeling of comfort, security and friendliness felt by consumers.

The effect of the promotion on the satisfaction of the inpatient patient of Muhammadiyah Ahmad Dahlan Hospital Kediri

The results showed that there is a significant influence of promotion on patient satisfaction obtained $\mathrm{p}$ value $=0.00<\alpha=0.05$, so $\mathrm{H} 0$ rejected $\mathrm{H} 1$ accepted. The conclusion is promotion has a significant effect on the satisfaction of inpatients of Muhammadiyah Hospital Kediri.

According to Kotler (2012) promotion is a tool used for communication with target markets that are persuasive. Marketing must also communicate to customers on a promotional basis. Elements of promotion mix of advertising, sales promotion such as exhibitions, awards, demonstrations, public relations. According Totok Sudarto (2011) promotion is any form of communication used to inform, persuade or remind people about the products produced by an organization, individual or household.

Based on the results of distribution based on marketing promotion mix showed that from 240 respondents almost all respondents that as many as 234 respondents $(97.5 \%)$ stated that the promotion is good. Patient satisfaction is good to promotion that is 232 respondents $(96,7 \%)$, from result of Spearman rho got $p=0,00$ meaning that there is relation between promotion of respondent with satisfaction of patient of inpatient of Muhammadiyah Hospital Kediri. A number of promotional efforts have been done by Muhammadiyah Hospital through electronic media, print media, and internet (social networking). Muhammadiyah Hospital already has its own website, and do promotion through you tube. 
The effect of the people on the satisfaction of the inpatient patient of Muhammadiyah Ahmad Dahlan Hospital Kediri

The results showed that there is significant influence people on patient satisfaction obtained $\mathrm{p}$ value $=0.00<\alpha=0.05$, so $\mathrm{H} 0$ rejected $\mathrm{H} 1$ accepted. The conclusion drawn is that people have a significant influence on the satisfaction of the inpatients of Muhammadiyah Hospital Kediri.

According to Zeithman and Berry (in Tjiptono, 2014) aspects of patient satisfaction include the privilege of the patient feeling privileged by the officer during the service process.

In Muhammadiyah Hospital every officer is equipped with skill according to skill, it is proven that there are training certificate, ACLS, BLS for doctors and nurses. Midwives should also have CTU training, partus training, antenatal, postnatal, infant care. Training of nutrition officers, drugs are also not left behind. All must be competence-based. Enhancement of human resources in addition to reserved for medical officers, paramedics and non-medical personnel who support the quality of hospital services. In addition to the internal aspect, there must also be an increase in HR from the external side. Effective communication training, patient handling, excellent service / service excellent continue to be improved.

The effect of the process on the satisfaction of the inpatient patient of Muhammadiyah Ahmad Dahlan Hospital Kediri

The results showed that there is significant effect of the process on patient satisfaction obtained $\mathrm{p}$ value $=0.00<\alpha=0.05$, so $\mathrm{H} 0$ rejected H1 accepted. The conclusion taken is the process has a significant effect on the satisfaction of inpatients of Muhammadiyah Hospital Kediri.

Based on the results of the marketing mix distribution process showed that almost all respondents were 234 respondents $(97.5 \%)$ stated that both the process and the satisfied patients are 234 respondents (97.5\%), from Spearman rho results obtained $p=0.00$ meaning that there is a relationship between the process with the satisfaction of inpatient hospital Muhammadiyah Hospital Kediri.

The effect of the physical building on the satisfaction of the inpatient patient of Muhammadiyah Ahmad Dahlan Hospital Kediri

The results showed that there is significant effect of physical building on patient satisfaction obtained $\mathrm{p}$ value $=0.00<\alpha=0.05$, so H0 rejected $\mathrm{H} 1$ accepted. The conclusion taken is the physical building has a significant effect on the satisfaction of inpatients of Muhammadiyah Hospital Kediri.

According to Zeithmal and Berry (in Tjiptono, 2014) aspects of patient satisfaction include aesthetics, where aesthetics in the service related to the suitability of the layout of space, as well as the beauty of the room. Physical evidence is the physical environment in which services are created and directly interact with consumers. The importance of this physical evidence greatly affects patient satisfaction. Elements that include physical facilities include physical environment, physical building, equipment, equipment and other goods which are incorporated with the services provided. The physical environment provided by hospitals as a place for health services should pay attention to design and appearance.

From the observation result Muhammadiyah hospital is a hospital with the category of building is new, and clean. Color composition is good. The hospitalized section for children on the wall is an interesting drawing. Good light arrangement and light. Air circulation is also sufficient. The arrangement of the room is also good. 
Factors that effect the satisfaction of the inpatient patient of Muhammadiyah Ahmad Dahlan Hospital Kediri

Based on the results of this study showed that of the seven variables after multiple linear regression test all variables of marketing mix 7P (product, price, place, promotion, people, process, physical building) affect the satisfaction of inpatient patients RS Muhammadiyah Ahmad Dahlan Kediri that influence City of Kediri.

The results of this study indicate that there is an influence between the marketing mix and patient satisfaction. This is evidenced by the $t$ test that the significance is 0.00 , where the value is $<0.05$. Thus it can be said that the marketing mix is very influential on patient satisfaction inpatient Muhammadiyah Hospital Kediri. From the simultaneous test F, also significant $\mathrm{p}$ value $<0,05$.

\section{The most dominant factor affecting the satisfaction of inpatients of Muhammadiyah Hospital Kediri}

Based on the results of multiple linear regression statistics test obtained the most dominant physical building value of 0.442 in influencing patient satisfaction means a good building and complete facilities, room and arrangement of a nice and attractive room, cleanliness of the place and air circulation room good hospital, medically complete enough to greatly affect patient satisfaction.

From physical building indicator, the most influential indicator is room and arrangement of good and attractive room, medical equipment that is complete enough. Here it is possible because Muhammadiyah Hospital includes a new building that looks magnificent from the outside. The building architect is also nice. The color composition of the building is also interesting.

\section{CONCLUSIONS AND SUGGESTION}

\section{Conclusions}

1. Based on the research result, the distribution of marketing mix frequency is as follows: good product $(98,8 \%)$, good price $(97,9 \%)$, good place $(97,5 \%)$, good promotion $(97,5 \%)$, (97,5\%), good process $(97,5 \%)$, physical building $(97,9 \%)$, patient satisfaction $(97,9 \%)$

2. There is influence of product price, place, promise, peple, process, physical building to the satisfaction of inpatient hospital Muhammadiyah Ahmad Dahlan Hospital Kediri. And the most dominant factor that influences is the physical building factor.

\section{Suggestion}

1. Bagi respondents

To be able to improve the knowledge and understanding of the respondents about the hospital marketing mix useful to know the level of patient satisfaction

2. For the place of research Muhammadiyah ahmad Dahlan Hospital Kediri City Attempts to improve marketing mix strategy from various aspects of $7 \mathrm{P}$ (product, price, place, promotion, people, process, physical building) so that patient satisfaction can be achieved.

3. For Educational institutions

Continue to develop research on the marketing mix of different variables and also from different hospitals.

4. For Further researchers

Researchers are expected to further develop this research by examining other factors related to the marketing mix of patient satisfaction. 


\section{BIBLIOGRAPHY}

Alfianti, K.R. \& Karimun, R. (2017). Hubungan Bauran Pemasaran (Marketing Mix) Dengan Keputusan Pasien Rawat Inap Memilih Layanan Kesehatan Di Rumah Sakit Umum Propinsi Sulawesi Tenggara Tahun 2016, Jurnal JIMKESMAS Ilmiah Mahasiswa Kesehatan Masyarakat VOL. 2/NO.5/ ISSN 250-731X.

Alma, B. (2013). Manajemen Pemasaran dan Pemasaran Jasa. Bandung. Alfabeta.

Azwar, A. (2010). Pengantar Administrasi Kesehatan. Binarupa Aksara EGC. Jakarta.

Depkes. (2014). Profile Kesehatan Indonesia. Retrieved Pebruari 10, 2017, from www.depkes.go.id/download/pusdatin.

Faisal Makassar Tahun (2011). Jurnal Administrasi Kebijakan Kesehatan, I(1) September 2012.

Hurriyati, R. (2010). Bauran Pemasaran Dan Loyalitas Konsumen. Bandung : Alfabetha.

Kotler \& Keller. (2012). Marketing Management, 14 th ed. Person Education.

Notoadmojo \& Soekidjo. (2010). Metodologi Penelitian. Jakarta : Rhineka Cipta.

Nurlia, C. (2011). Hubungan Bauran Pemasaran Dengan Keputusan Pasien Rawat Inap Memilih Layanan Kesehatan Di Rumah Sakit Islam.

Permenkes RI No. 56 tahun (2014) tentang klasifikasi Rumah Sakit.

Priyanka. (2013). Pengaruh Bauran Pemasaran Terhadap Jumlah Kunjungan Pasien Di Poliklinik Rawa Jalan Rumah Sakit Umum Daerah Sanjiwani, Gianyar. Tesis.

Rengkuan, S.R., Kandou, G.D., \& Tilaar, C. (2015). Hubungan Antara Persepsi Pasien Umum tentang Bauran Pemasaran Jasa dengan Loyalitas Pasien di Instalasi Rawat Jalan RS Advent Manado.

Siyoto,S. \& Supriyanto. (2015). Kebijakan Dan Manajemen Kesehatan. Andy Offset. Yogyakarta.

Supriyanto \& Ernawaty. (2010). Pemasaran Industri Jasa Kesehatan. Yogyakarta : Andi Pustaka.

Tafdilla, A.S. (2015). Pengaruh Persepsi Pasien Tentang Bauran Pemasaran Terhadap Keputusan Pasien Rawat Jalan Memilih Layanan Kesehatan Di RSUD Majenang Tahun 2015, Universitas Negeri Semarang.

Tjiptono, F. (2014). Pemasaran Jasa. Yogyakarta: ANDI.

Toding, E., Palutturi, S, \& Nurhayani. (2013). Hubungan bauran pemasaran dengan minat kembali pasien rawat inap RSIA Elim Makassar. Universitas Hasanudin.

Wijono, D.J. (2011). Manajemen Mutu Pelayanan Kesehatan: Teori2 Strategi dan Aplikasi Volume. 2. Cetakan 24 Surabaya. Erlangga University Press. 